Open Access

\title{
Chinese one-child families in the age of migration: middle-class transnational mobility, ageing parents, and the changing role of filial piety
}

Mengwei Tu(D)

Correspondence: mt362@kent.ac.uk School of Social Policy, Sociology and Social Research, University of Kent, Second Floor, Cornwallis East, Canterbury, Kent CT2 7NF, UK

\begin{abstract}
One-child transnational families are the product of the "one-child" policy, access to foreign travel, and the rise of a middle class that could afford overseas education for the only child. One result was the possibility of the only child, following its Western-based education, settling (semi)permanently in the host country. This situation raises the issue of how the only child balances the opportunities in the West with the filial responsibilities to ageing parents back in China. Recognising the diversity of family forms, this study highlights the "human story" of ageing and intergenerational relations in families split between China and the UK. Drawing on 40 interviews, which included one-child migrants in the UK and some of their parents in China, this article explores the views of both generations. The findings indicate that international migration and increased family affluence did not lead to the erosion of filial piety. However, the practice and perception of filial piety among these families underwent a complex transition. Distance and borders posed future significant barriers for parental long-term care. One-child migrants tended to compensate for the lack of material/practical care by providing long-distance emotional care for their parents. Both generations expressed ambivalence towards this new transnational family contract. Instead of focusing on the practical outcomes, this article argues for the importance of examining how the members of transnational families perceive their filial behaviour. This focus brings out the less visible changing dynamics of intergenerational care in the context of modernisation and globalisation.
\end{abstract}

Keywords: Ageing, Transnational family, Filial piety, Chinese migration, One-child family

\section{Background}

The late twentieth century marked the start of dramatic socioeconomic changes for families in China. The post-1978 economic reform witnessed the rise of a new "middle class" in China (Li 2010a). The increasing household wealth of this class was coupled with sharply reduced family size as a result of the "one-child" policy initiated in 1979. The "one-child" policy was officially ended in October 2015. However, the three and half decades of policy implementation created a one-child generation and made the three-member nuclear family the norm in urban China.

(c) 2016 The Author(s). Open Access This article is distributed under the terms of the Creative Commons Attribution 4.0 International License (http://creativecommons.org/licenses/by/4.0/), which permits unrestricted use, distribution, and reproduction in any medium, provided you give appropriate credit to the original author(s) and the source, provide a link to the Creative Commons license, and indicate if changes were made. 
The only child in middle-class families benefited from concentrated family resources. With a desire for Western affluence (Li 2010a; Fong 2004) and the increasing opportunity to go abroad, the number of Chinese students studying abroad has sharply increased since the turn of the century (from 17,662 in 1998 to 38,989 in 2001 to 459,800 in 2014 [National Bureau of Statistics of China 2015]). The majority of overseas Chinese students were postgraduate students in their 20s ( $\mathrm{Li} 2010 \mathrm{~b}$ ) with the USA and the UK being the two most popular destinations.

A large number of graduates remained in the host country and extended their stay indefinitely. The PRC's survey of the period 1978-2006 reported that $70 \%$ of the Chinese who went abroad as students remained overseas after graduation (Jiang 2009). The return rate remained lower than half until shortly before 2010 (National Bureau of Statistics of China 2015). The increased return rate was the result of tightened migration policies and limited job vacancies in most Western student-receiving countries after the 2008 financial crisis, as well as expanding career opportunities in China. The Annual Report on the Development of Chinese Returnees (2013) indicated that among graduates aged between 24 and 30 who returned after studying abroad in 2012, 90.9 \% of them chose "to be near parents" as one of their main reasons for returning (Wang and Miao 2013).

What about the one-child graduates who, for various reasons, did not return and could not "be near parents"? What will happen (or is happening) to their relationship with parents in China? Given the family-based parental long-term care in China, how will traditional intergenerational practices, such as filial piety, be re-interpreted in a long-distance family setting? The one-child transnational family phenomenon is a unique "transnational social field" (Levitt and Schiller 2004) in which to examine ageing and intergenerational relations in the context of modernisation and globalisation.

\section{Filial piety and twenty-first century urban families}

In Chinese families, the notion of filial piety has been the dominating "cultural logic" for more than 2000 years (Zhan and Montgomery 2003). It is arguably one of the oldest forms of family contract. The definition of filial piety in the twenty-first century varies slightly according to different scholars in different contexts (Schans and de Valk 2011; Chow and Chu 2007; Croll 2006; Ikels 2004). In general, filial piety requires children to fulfil parent's practical and financial/material needs and look after a parent's emotional well-being; it also traditionally prescribes obedience and respect from the younger to the older generation regardless of an individual's age (Keller et al. 2005).

However, findings in Asia from the late 1990s indicated a declining emphasis on reverence and obedience but a trend towards renegotiating intergenerational filial expectations based on more egalitarian intra-familial exchanges (Croll 2006). The more recent evidence suggests a gradual shift in filial practices from gender specific to relatively gender flexible (Shi 2009; Xie and Zhu 2009; Wang 2004). Thus, filial piety and family values should be understood in their specific sociocultural contexts (Hu and Scott 2014).

Outside the family, filial piety requires "conducting oneself so as to bring honor and avoid disgrace to the family name" (Chow and Chu 2007, p. 93). Likewise, an individual's "filial demonstration" towards his/her parents establishes him/her as "a reliable, trustworthy and honourable person" in the eyes of others (Ikels 2004, p. 5; Whyte 2004). In 
contemporary Asia, urbanisation has reduced to some degree the direct enforcement of filial piety by local patrilineal communities. Nevertheless, indirect social pressure to conform to the culturally prescribed filial norms is still pervasive, as the findings of this study indicate.

Apart from families and communities, the state has promoted the traditional family contract through legislation on children's responsibility of parental care ${ }^{1}$ and minimising the state's role in long-term care for the elderly (Feng et al. 2011; Zhan et al. 2008). To date, there is no functioning elderly care system in China. Long-term care institutions have varied standards and policies. Government-funded care institutions accept only the very desperate elderly (Wu et al. 2008), while high-quality (private) care homes cater for only very affluent clients (Zhan et al. 2008).

A gap remains for the vast group in the middle: $90 \%$ of the elderly still relied on familial care in 2012 (Zhang 2012). In 2014, there were more than 36 million bedridden or semi-bedridden elderly people in China but only 356,000 care staff and 50,000 certificated carers for the elderly (Wang and Tian 2015). These realities are likely to pose long-term care problems even for middle-class urban residents. It is important to note here that parents of the one-child migrants, at the time of the research, were not yet elderly enough to need intensive care. However, the availability of non-familial care in the near future should not be taken for granted.

This article aims to further the understanding of the twenty-first century Chinese family contract by studying not only what family members do to reciprocate intergenerational support but also how they perceive their (expected) filial behaviour. Rather than assuming that modernisation/globalisation and traditional family values are two opposing elements (the former erodes the latter, the latter slows down the process of the former), this research investigates how contemporary Chinese family contracts (mainly to do with filial piety) are being reconfigured and renegotiated in "the age of migration" (Castles and Miller 2009).

\section{Chinese middle-class transnational families}

Studies of affluent Chinese transnational families have been based largely on transPacific families: Chinese families from more developed regions in Asia (such as Hong Kong, Singapore and Taiwan) migrating to North America and Australasian countries (Lin 2011; Waters 2005; Chee 2003; Ong 1999). This migration included the phenomenon of the "astronaut family", where one parent accompanied the child to the host country while the other parent (usually the father) stayed in the home country to earn money and travelled regularly between his family and work (Tsong and Liu 2009; Huang and Yeoh 2005; Ong 2003). Similarly, widely used terms like "Pacific shuttle" and "parachute kids" (Ley 2010; Tsang et al. 2003; Zhou 1998) also reflected an education-motivated, child-centred trans-Pacific migration arrangement. These family members were described as being highly mobile, flexible "global citizens" (Ong 1999) for whom notions of the "nation-state" became irrelevant (Yang 2011; Wong 2003).

Such narratives located the transnational dispersion of middle-class families within "late capitalism" where the "speedup of all aspects of economic life" generated new flexible production, consumption and accumulation of capital (Ong and Nonini 1997, p. 10). People worldwide "no longer see their lives as mere outcomes of the givenness of things, 
but often as the ironic compromise between what they could imagine and what social life will permit" (Appadurai 1996, p. 54). Although this approach explains the "new" Chinese mobility as an active family capital-accumulating strategy, it risked over-simplifying middle-class Chinese families' transnational practice by assuming a similar (high) level of flexibility and sustainability.

By pointing out the difference between Singaporean and other new East Asian migrants, Lin (2011) argued for the "possibility of alternative realities within many Chinese transnationalisms". The rising participation of middle-class families from China at the turn of the century has certainly further diversified the profile of the new Chinese transnational families. Unlike trans-Pacific astronaut families, the typical pattern of the one-child transnational family in this study is that both mother and father live in China while the only child lives overseas. Compared with the astronaut families, the one-child families have a lower level of transnational flexibility given the lack of a sibling to share parental care in the long term. Following this, I argue for a micro-level approach to examining Chinese families' transnational mobility by focusing on the relationship between ageing parents and migrant children.

So far, approaches to Chinese transnationalism have largely regarded the parents as supporters of the new Chinese mobility and their offspring as the beneficiaries, which assumes an on-going parent-to-child transfer. However, intergenerational transfer is not always a one-way process. Family support dynamics change as the two generations age. What the literature lacks is a two-way perspective, which examines the sustainability of Chinese transnationalism as family members grow older (including parents becoming retired and elderly, as well as children leaving home and having families). Life cycle plays a crucial role in determining individuals' emotional/material needs and migration decisions (Bryceson and Vuorela 2002; Lee 1966) and also transnational families' migration strategies (Waters 2011). In the case of the one-child transnational families, where parents and only children are separated by distance and borders, the tension between the needs of ageing parents and a child's overseas settlement is likely to be increasingly accentuated.

\section{Between China and the UK: the post-education transnational field}

Migration from mainland China to the UK has sharply increased during the past two decades (see Fig. 1). In 2012, China ranked as the top (non-EU) migrant-sending country to the UK for the first time (ONS 2013a). The arrival of the new Chinese migrants from mainland China has changed previous Hong Kong (Cantonese) dominance of the UK Chinese demographic. The percentage of the UK ethnic Chinese population originating from mainland China rose from $13 \%$ in 1991 (Cheng 1994) to nearly $40 \%$ in 2011 (ONS 2012).

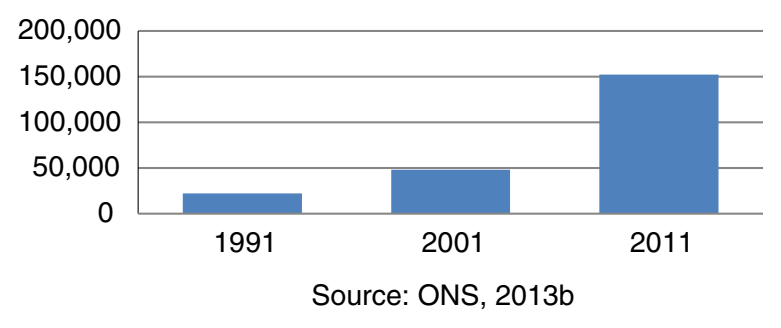

Fig. 1 China-born residents in the UK (2011 Census) 
Students aged 16 and over made up $45 \%$ of the Chinese who arrived between 2001 and 2011 (ONS 2013b). By 2012 China provided the largest number of international students in UK universities, making up almost a third of non-EU students (Universities UK 2014; Home Office 2013). Based on the relative young age of the arrivals it is reasonable to assume that the majority belonged to the one-child generation in China who were born after the late 1970s. In this study all respondents but one arrived in the UK after 2000, and they were all below the age of 30 in the year of their arrival. The majority of the sample extended their post-education stay by switching to working status and most of these were working as professionals in various mainstream industries. Compared to the previous Chinese migrants this cohort had greater socioeconomic upward mobility in the UK. Compared to their counterparts in China, the overseas one-child cohort was believed to have obtained "First World" affluence (Fong 2004) given that overseas education was considered a "gateway to the ultimate goal of a life in a more open and affluent Western society" (Bodycott and Lai 2012).

However, parents of these one-child migrants showed a lower degree of mobility when compared to their counterparts in trans-Pacific families. Unlike middle-class parents from Hong Kong and Singapore, for whom international migration had been a central feature of their family history (Göransson 2009; Waters 2005; Skeldon 1994), mainland Chinese parents were deeply rooted in their home community. The Chinese border was closed during Mao's regime, and private migration has been made possible only since the 1980s (Liu 2011; Liu 2006). Administratively, the parents' generation had been embedded in the communist style Danwei (work unit) system, which monitored its members' work and life ( $\mathrm{Hu}$ and Peng 2015). Almost all the respondents participating in this study were the first generation in the extended family (from their grandparents' generation) to have gone abroad, which has widened the generation gap between migrants and their parents.

In addition, the tightening of UK immigration policy during the past decade made long-term settlement in Britain more difficult. Consequently and ironically, the "value" of permanent British residency (possessed by the younger generation) was increased and was more likely to be viewed as a "family asset" not to be easily given up. Indeed, several respondents regarded "getting a British permanent residency permit" as an important part of their overseas achievement. This kind of space-bound capital accumulation strategy reduced the transnational flexibility for both generations. Therefore, the contemporary middle-class migration pattern between China and the UK cannot be assumed to be "circuits of transnational migration", which was how Waters (2005) described middleclass migration between Hong Kong and Canada. Rather, the UK-China "transnational social field" (Levitt and Schiller 2004) is more stable and bounded by national borders. Hence, it is likely to pose dilemmas for the two parties in renegotiating family obligations and responsibilities.

\section{Method}

My empirical data derives from 40 semi-structured interviews (27 one-child migrants, 6 migrants with siblings, 7 sets of migrants' parents) conducted in the UK and China during 2013-2014. Snowball sampling was used in conjunction with online advertising. These two strategies proved useful in overcoming the geographical barriers in reaching out to the potential participants, who were dispersed throughout the UK and China. 
The 27 one-child migrants were interviewed first and then asked if they would connect me to their parents in China. Eventually, seven sets of parents ${ }^{2}$ in China took part in the research. Interviewing both child and parents from the same family is rare in transnational family research, largely because of the practical difficulty of accessing both children and parents. The six migrants who had siblings were interviewed as a supplementary resource to provide a point of comparison with the only-child families.

Interviews lasted between 1 and $3 \mathrm{~h}$ and were audio recorded. The word "children" is used for the convenience of analysing the parent-child relationship; in fact, these migrant "children" were between 22 and 38 years of age, and nearly a third of them had British-born offspring. The parents of the migrant children I interviewed were aged between 51 and 68 years. At the point of interview the majority of parents had not reached retirement; most were working as professionals and a few were business owners. The majority of the parents were not elderly (or ill) enough to need intensive care, ${ }^{3}$ but as parents continue to age, their need for physical care would become more pressing. This study may not observe the outcome of the physical care arrangements, but it captured how parents and children saw their roles in the intergenerational care arrangement during the process of negotiation.

The sample comprised 20 women and 13 men, which may reflect the gender balance among post-education Chinese migrants. While there is currently no reliable data on the gender ratio among middle-class Chinese migrants in the UK, more Chinese women than Chinese men graduated from UK higher education institutions between 2001 and 2011. Women outnumbered men in Master's and undergraduate programmes by a ratio of 1.5:1 in 2008/09 (Iannelli and Huang 2013).

The participants came from a variety of regions in China, which is in keeping with what is known about the new mainland Chinese migrants: they not only came from coastal migrant-sending regions like Shanghai and Guangdong (near Hong Kong) but also from inland provinces which were not traditionally migrant-sending regions. The migrants had lived in the UK for 1-13 years and were at different stages of their lives; the samples included 5 postgraduate students and 27 post-education migrants; 14 were married and 19 were unmarried. ${ }^{4}$ That the respondents were at different stages in their career and marital status provided further material for analysing the impact of the life cycle on transnational families.

\section{Migrants' perspective: transnational family challenges and responsibility shift}

One-child migrants faced two challenges in terms of looking after their parents. The first and more pressing matter is to do with coping practically with any emergency in the life of the parents in China. As Ran (male, 27, software engineer) emphasised: "I need to be able to go back within a few hours' time, not the next day. In some emergency situations it would be too late." In comparison, Chuanli (male, 31, post-doctoral researcher, has a sister) thought his sister's physical proximity to their parents gave him "peace of mind". The other problem is the difficulty of having parents come to live with the child in the UK because of immigration policy and concerns about parents' wellbeing in a new country. The British government has severely limited residency permits granted to "elderly dependent relatives" who come for family reunification. Furthermore, if parents were to settle in the UK, their lack of English, together with lifestyle changes, 
could constitute a potential threat to their psychological well-being by increasing their dependency on their child, thereby reducing their own mobility.

To what extent did these transnational family challenges impact on migrants' settlement plans? It is important to look at this question together with other factors which shape the on-going process of migration decision-making (Mosneaga and Winther 2013). When the respondents arrived in the UK as students, few of them had a long-term settlement plan. Migrants' decision-making process usually evolves alongside significant life events: study abroad, graduation/employment, relationship/marriage and becoming parents. Alongside these significant decision-making points, external factors, especially to do with job opportunities, migration policy and unexpected events, all had different levels of impact on their decision to remain or to return to China.

The longer children remained in the UK, the more established their families and careers became, which meant that migrant children had more to lose when returning to China. In other words, the economic and social capital one-child migrants accumulated through overseas education and post-education experience may decrease following return migration. Unlike a Western university degree, whose "value" is transferable across borders, other forms of "capital" were not always transferable, including (some aspects of) work experience, professional/social connections, and the quality of the migrant's family life in the host country.

As a result, married respondents generally expressed a stronger wish to settle in the UK; unmarried respondents (single or in a relationship) tended to speak in favour of returning to China. While career prospects were an important factor in respondents' decision-making, two single men and one single woman saw parental needs as the dominating factor and had planned to return to China solely because of it. By contrast, the married migrants, especially those who had offspring, generally lived in the UK for a longer period and were more established in the host society. They regarded the next generation's well-being in the UK as their primary responsibility.

It cannot, however, be assumed that the unmarried respondents were "more filial" and the married respondents were "less filial". Behind the differences in settlement choices was the shift (and compromise) in family responsibilities that migrants experienced before and after marriage. Compared to the unmarried respondents, the married respondents had a very different way of seeing their role in migration decision-making: responsibilities not only expanded from the natal family to their own nuclear families, but sometimes also to the in-laws (especially if the spouse was also a one-child migrant). As Demin (male, 33, lecturer) put it:

Any decision you make, is the result of compromises after taking all aspects into consideration: not just your parents, but also your spouse, your child and your spouse's parents. All of them.

In this complex decision-making web, as described by Demin, the influence of parental needs had clearly (temporarily) lost its once dominating position. It is worth noting here that the married women and men in the sample showed a similar pattern of commitment transfer from parents to their own nuclear family. However, with 10 married one-child women and only 2 married one-child men (in spite of attempts to recruit a gender-balanced married sample), it was difficult to make any meaningful gender 
comparisons in terms of the impact of marriage on a one-child migrant's sense of filial piety.

The one-child migrants' parents were relatively young, which enabled migrants to focus on their own child(ren) rather than on the care needs of their parents. By the time parents are elderly with decreased mobility (in their 70s and 80s), migrant children will be in their late 40s to 60 s with grown up child(ren). This useful spacing was mentioned by a number of one-child respondents (married and unmarried) as a justification for making parental care responsibility secondary to the needs of their own family (or career) at the current stage of the respondents' lives. The relative youthfulness of Chinese parents avoided the caring "squeeze" which is more commonly found in British families, in particular, among the higher educated women whose childbearing is delayed and who are more likely to face the expectation of "two-way" ("downward" to children and "upward" to parents) care (Agree et al. 2003).

This child-centred support flow put one-child migrants at an advantage in terms of socioeconomic mobility in the host country. However, for adult children, not being able to reciprocate parental investment in a direct and tangible way can result in serious frustration. In interviewing older Taiwanese migrants (aged above 60) who came to the USA when they were young, Sun (2014) found that these migrants' care duties to their elderly parents in Taiwan were shared by their siblings. However, in spite of sending regular remittances to their parents and sibling, these migrants believed they still had unfulfilled moral obligations. In a similar study, Italian migrants in New Zealand were found to relinquish their claims to inheritance in order to compensate, financially and morally, for their sibling's larger share in parental care (Baldassar 2007).

However, unlike the Taiwanese and Italian migrants, the one-child migrants I interviewed did not have siblings to share their parental long-term care responsibility nor did they send remittances regularly. Parents' financial independence (in some cases financial affluence) made remittances from the UK to China redundant. On the contrary, financial transfer from parents to children was based on the mutual understanding that the only child was the sole beneficiary of parental assets. The oldest female respondent in the sample, Bolin (38, export manager) had a British husband, was the mother of two children (aged 8 and 9) and was the recipient of continuing financial and childcare support from her parents. While emphasising her commitment to settling in the UK and the priority of her children, Bolin also expressed a high level of emotional and moral pressure:

They [Parents] want to give everything to me, but they fear to trouble me with anything. I'd rather they loved themselves more than they loved me, I'd rather that they have asked something from me...this love is too heavy.

Co-existing with the sense of guilt and indebtedness, the respondents also expressed different levels of reflexivity on the more abstract elements of filial piety as a justification for choosing career/family development in the UK. Making parents proud, as explicitly expressed by four one-child migrants (two women and two men), was also highlighted as essential to being a filial child.

You need to ask yourself: "What do parents want from you?" Do they want you to be with them, or do they want you to be independent with your own career and life? I 
used to think filial piety was to be near your parents and look after them. Now I realise the importance of successfully managing your own life, not to let parents worry about you, and make them proud. I think this is also a form of filial piety (Wen, female, 33, married, legal assistant).

Such an understanding was in accordance with the traditional concept of filial piety that "a child's achievement is not only a matter of personal success, it brings honour to the family" (Göransson 2009, p. 119). However, other aspects of filial piety, such as physical closeness and material support, are compromised in the transnational onechild families. It is not yet known whether one-child migrants' responsibilities will shift towards parents in the future. Both parents and children in this study were struggling to come to terms with the new family contract in a fresh geographical setting. While the only child felt the practical and moral dilemma of remaining in the UK instead of returning for their parents, parents also had mixed emotions about the asymmetrical intergenerational support.

\section{Parents' perspective: ambivalence towards the "new family contract"}

A Chinese adage says "raise children for old age care" (yang er fang lao), which implies a reciprocal principle of parents investing in children's upbringing and well-being in exchange for old age care from children. The heavy investment in the only child observed among working class Chinese families in the 1990s was explained by Fong as a way to "enable singletons to achieve...success necessary for the fulfilment of their filial duties" (Fong 2004, p. 157). However, middle-class parents interviewed in this study explicitly spoke against this view by emphasising that such a concept belonged to "the previous generation", that it was "not necessary or realistic nowadays", and, most of all, the financially independent parents did not want to become a "burden" to their only child. Such attitudes confirmed Zhang and Goza's (2005) findings, a decade ago, that wellpaid professional parents did not want or plan to rely on their only child in their old age; they were willing to invest most of their income on the child, a pension scheme and a care home, but did not expect a financial return.

The middle-class parents in this study (and in Zhang and Goza's study) were very similar to their counterparts in Singapore: middle-class Chinese Singaporeans born in the 1960s and 1970s, who Göransson (2009) described as the "sandwich generation", attained affluence as a result of the rapid economic growth in the late twentieth century. "Sandwich" here does not mean the mid-age couple struggling between the needs of the elderly and the young; the term refers to the generation between the "old traditions" and the "modern world". Like parents in this study, the Singaporeans "sandwich generation" in the twenty-first century enjoyed a comfortable lifestyle and were able to provide high-quality material and educational resources for the next generation. Such a lifestyle stood in sharp contrast to their childhood experience. When faced with "intergenerational discontinuity" (Göransson 2009, p. 35), Singaporean parents used strategies to manage generational difference in everyday interactions with their children and their parents. However, parents in my study lacked the everyday physical and social space to bridge the generational gap.

As Göransson pointed out, the so-called sandwich generation was a class-related phenomenon and did not apply to all members of that age group. Likewise, in China, 
the middle-class parents were the minority of the generation born between the 1950s and the 1960s. Furthermore, the number of middle-class parents whose only child remained overseas made up an even smaller proportion of that generation. Therefore, parents of one-child migrants became the "modern minority" in comparison to "the more conventional majority" in their community.

Most parents interviewed in this study were aware of their "difference" from "other parents". For example, they promoted "modern elements" of family relations, such as a more "open, democratic" parent-child relationship and a less dependent older generation, in contrast to their observation of more "traditional" families around them. However, the parents' tendency to hide negative feelings from me (sometimes from their child as well) may have obscured the other side of the "modern story".

Given that filial piety is "everybody's business" (Ikels 2004, p. 5), parents of one-child migrants risked negative peer pressure in a society where the importance of family members' "physical closeness" was still pervasive. One mother cited her colleague's "half-joking" comment on the "side-effect of sending the only child abroad" to show that by letting her daughter remain overseas, she became the "different" minority among her peers. While parents may have promoted their "modernness" to me or took pride in it to justify the transnational relationship with their child, there could be more serious struggles between the "more modern individual" and conservative social norms in the local community.

Zhaohui (female, 23, student) came from a small town in South China (north Guangdong Province). Although its residents were officially categorised as urban citizens, the town was geographically and socially located at the periphery of urban development and a traditional (largely rural) social norm was still pervasive. Zhaohui reported that some parents in her home town prevented their child from going to university so that the child would not leave the parents. After her mother was paralysed several years ago, instead of being a "filial daughter" and taking up the role as her mother's carer, Zhaohui came to do her Master's degree in London and was determined to achieve high results:

In our small town everyone knows what everyone's children are doing, they'd compare with each other. I want my Dad to be able to tell others with pride when he was asked about me...I know he suffered a great deal from the gossips.

Zhaohui's father (56) became semi-retired from his job as an accountant in order to look after his paralysed wife and his aged mother. When asked for his opinion about his daughter being far away, he replied:

I had the chance to leave [the small town] when I was young, but I stayed for my parents, now I regret it...It's a different time now. It's not good to tie your child to you. I know some parents want their child near, but I have let the kite go loose. She can fly as far as she wants.

This parental struggle with peer pressure was more likely to be found in more conservative regions in China (like Zhaohui's home town), whereas parent respondents from big cities tended not to report direct social pressure. However, in spite of the 
dominating positive feelings parents reported about the "generational leap" (Göransson 2009 , p. 52), there was still a sense of disappointment among parents.

Ran's (male, 27, software engineer) mother (51, businesswoman) encouraged her son to study abroad and continue working in the UK. She expressed a great sense of satisfaction about her son's achievements but also used the word "unfair" when talking about the changes in filial practices between generations:

Sometimes I said to my husband, that we are more or less the last generation that need to materially support our parents for filial piety. We do not need the next generation to materially support us when we are old and we are also left alone by the next generation (Laugh). My generation is the most exploited. We need to look after the previous generation, but the next generation is not going to look after us.

Because of the limited size of the parent sample, it was unclear to what extent parents felt negatively about the generational difference. Nevertheless, the evidence from the interviews indicated a degree of struggle in coming to terms with the generational changes not only in comparison with the previous generation but also in comparison with their peers in the same generation. However, parents expressed feelings of unfairness and disappointment significantly less than the satisfaction they gained from their child's achievement and how they (parents) had contributed to it.

While children's addition to family honour by being successful is also a form of filial piety, transnational one-child families face a dilemma: migrant children's careers and their own nuclear families' well-being were geographically bound to the UK. The children's success in the developed host country meant compromising physical care (and some emotional care) towards parents in China. Therefore, in one-child households separated by long distance, some criteria of filial piety came into conflict with others. In such circumstances, distance plays a significant role in modifying filial obligations and expectations.

\section{Distance, intimacy and changing perception of filial piety}

"Distance lends enchantment" (or "absence makes the heart grow fonder") ${ }^{6}$; such proverbs describe how interpersonal attraction may be enhanced by individuals being away from each other. While a study of 63 dating couples in the USA supported such a claim (Jiang and Hancock 2013), there is no similar research about parent-child relationships. Nevertheless, evidence in this study suggested that both parents and children were aware of the role distance played in smoothing their relationships. The majority of both child and parent respondents indicated the importance of not living together under the same roof. Both generations' wish to live independently is not new. Surveys in the 1990s indicated urban Chinese residents' support for parents and children to "live close by but not necessarily together" (Ma et al. 1994; Hu and Ye 1991).

Different levels of tension with parents were reported among the migrants who for some reason shared a house with their parents over a substantial period of time (for example, when parents were helping to look after their grandchildren or when migrant children went back to China for a long holiday). The causes of arguments ranged from everyday nitpicking to disputes about child rearing. Conversely, not being able to see parents often made co-presence more precious. Ran (male, 27, software engineer) had 
authoritarian parents, yet he felt much closer to his parents during each home visit: "When you meet only two weeks a year, you tend not to argue with each other, you tend to feel closer." Chuanli (male, 31, post-doctoral researcher) who has a sister, also articulated a similar feeling regarding parents: "When you see parents on a daily basis you won't treasure that feeling [between parent and child]. I appreciated filial piety more after I left China." Overseas children were likely to develop a romanticised outlook on the parentchild relationship, therefore increasing the likelihood for them to support the notion of filial piety. Migrants' emotional support for parents was a significant element of the changed meaning of filial piety for them following overseas settlement.

Although the long distance between China and the UK limited the migrant children's practical support for their parents, they showed emotional support by practising "longdistance intimacy". The term "long-distance intimacy" was developed by Parreñas (2005) to describe the transnational intergenerational relations between Filipino migrant mothers and their young adult children left at home. As migration literature on transnational intergenerational relationships tends to focus on the migrants' relationship with their younger family members, such as children, research rarely addresses "intimacy" with older generations of families who are also separated from the migrants. Even less academic attention has been paid to middle-class migrants' relationship with their middle-class parents living in the home country.

"Empty nest" middle-class parents showed a significantly higher demand for emotional than material support. The development of International Communication Technology (ICT) in the twenty-first century has been celebrated for "generating new ways of living together and acting transnationally in the digital era" (Nedelcu 2012, p. 1339). Migrants in this study reported using ICT to maintain "long-distance intimacy". Both parents and migrant children could message, talk, and video chat with each other on a "smart phone" at a very low cost. Apart from a small number of respondents whose parents sometimes had to work at a weekend, the majority kept a routine of video chatting/telephoning with parents at least once a week at the weekends. The length of video chatting/telephoning typically lasted for around 1 hour each time, as reported by respondents. Video chatting happened more frequently among migrants who had child(ren) as the parents also wanted to "see" the grandchild(ren). Furthermore, other means of communication, like messaging (text or photo), took place even more frequently; in some cases, the respondents reported daily communication with parents.

However, not all the respondents enjoyed this kind of frequent communication with parents; a small number found such communication with parents psychologically demanding or practically difficult to balance. For example, Zhaohui (female, 23, student) found it difficult to express intimate emotion to her father; Ran (male, 27, software engineer) felt guilty: "if my Mum don't call me, I'd forget to call her, then she'd be unhappy about it." Dahong (female, 27, market analyst) kept daily messaging with her parents but said the content of the exchange was sometimes "boring" and "trivial". Nevertheless, in spite of the negative experience, these respondents still felt morally obliged to fulfil their parents' emotional needs by committing time and patience to long-distance communication.

Long-distance intimacy did not only manifest itself in how often the child and parents talked, or what they talked about but it also had to do with what was not said by parents and children. The respondents rarely contacted parents for their own 
emotional support, i.e. when they felt sad or anxious, they tend to rely on their spouse or friends (in the UK or in China) for emotional support. "Only tell parents good news" was the "golden rule" mentioned frequently by the respondents; any emotional distress expressed by the migrant child would also bring anxiety to parents, and thus it was wiser not to reveal negative emotion to parents.

The golden rule of only tell good news was also practised by some of the parents of one-child respondents. For example, the incidences of a close relative's death or parents' own illness was not revealed to the child until a few months later. The earlier remark from Bolin (female, 38, export manager), "they [parents] fear to trouble me with anything", also indicated the parental tendency to look after their child's emotional well-being by not becoming an emotional (and practical) liability. Because of the limited parent sample, it was not clear how common, or to what extent, parents hid their negative emotions in their communication from their migrant child. Nevertheless, the existing cases in this study showed the delicacy of long-distance intimacy: because of the lack of alternative means to learn about each other's life (e.g. physical visits), what parent and child chose to include, or not to include, during their communications was likely to have a greater psychological impact on each family member than in families who are not separated by distance and borders.

How do parents perceive the implication of long-distance communication with their child? Bolin's parents regarded frequent telephone contact as a sign of their daughter's filial piety to them. Bolin's mother cited an occasion as an example of her daughter's care for parents: Bolin shortened a Sunday family outing with her sons in order to get back on time to video chat with her parents. Although Bolin's parents took emotional comfort from the indication that they were their daughter's priority on that occasion, they had tried nevertheless to "push Bolin away". Bolin reported in her interview that sometimes while she was online chatting with her mother, her mother would ask her to stop the conversation and spend more time with her own children; thus, Bolin felt a sense of "selfless care" from her parents.

In this way, the international daily communication became a "dynamic of intimacy". It was important for children to contact parents in spite of inconvenience to show their filial piety, while it was also appropriate for parents to reject their child's "sacrifice" and not to impose parental emotional needs on children. Nevertheless, the children's failure to keep up with frequent communication caused parental anxiety or disappointment; as a result, the children's availability for international communication was vital to parents' emotional well-being. Thus, the cycle continues: between one-child migrants and their parents, it was the two parties' "sacrifice" and "anti-sacrifice" pattern that drove the dynamic of the intergenerational intimacy.

Dai and Diamond observed in the 1990s that, compared to American culture, which regarded limited responsibility from children to parents as the norm, Chinese culture encouraged unlimited responsibility and devotion to parents or family (1998). However, how parents and children perceive and discharge "unlimited responsibility" is clearly changing in the twenty-first century. An increase in investing in the younger generation and a decrease in the taken-for-grantedness of care-inreturn of the older generation has been consistent across Asian societies (Lee 2010; Göransson 2009; Croll 2006; Park et al. 2005). In the context of the middle-class one-child transnational family, children had very limited material responsibilities 
towards parents, and future care expectations were unclear. For now, it is the willingness to commit oneself to caring for parents' well-being, not necessarily the observable filial actions, that has been regarded by both generations as the priority of being filial.

\section{Conclusion}

In the age of migration, the aspirations and opportunities to pursue transnational mobility encouraged the movement of capital and population on a global level. Consequently, more and more families from traditionally family-oriented societies find themselves in a situation where parents and children are separated for a longer time and by a greater distance.

One-child transnational families are a minority (and new) family type in the context of a Chinese society which still regards "physical closeness" as the norm. Transnational family members are under social pressure to compensate for the "physical separateness" with a more pervasive emotional unity. Such emotional obligations of intergenerational reciprocity may be less visible in terms of how migrants and their parents behaved, but they still affected how they expressed their feelings about their (expected) filial behaviour.

Parents' and children's ambivalence about their situation, suggested a family contract in transition. First, in spite of evidence of a commitment shift after marriage in the UK, one-child migrants still regarded being filial to their parents as a moral obligation. Second, parents of the one-child migrants were caught between a more traditional reciprocal relationship with their own parents and a "reconfigured reciprocity" (Sun 2014) expectation from their only child. Finally, both parents and migrant children are the "minority" in their respective local societies. Separately, the two generations had to develop coping strategies against social pressure in China and in the UK. Therefore, the complex interpretation of family contract(s) was arguably the outcome of both generations coming to terms with the changing family form through a changed space (because of migration) and time (life cycle of family members).

It is important to note that the filial piety migrant children referred to was by no means static. When children were still in the phase of receiving support from their parents, they were more likely to indicate a willingness regarding filial support (Schans and de Valk 2011). Parents in this study were in reasonably good health, and their migrant children were largely the recipients of parental financial and care support. It should not be taken for granted that the offspring would be willing and able to return the parent's favour in the future. Therefore, the one-child generation and their parents have had to adapt themselves to new rules and dynamics of intergenerational support given their specific and likely future circumstances. In addition, when separated by long distances and faced with possible permanent household separation, only children and their parents faced unique challenges. There was no longer a standardised Chinese family contract. The changing environment enabled families to evolve into distinctive forms and acquire new mobilities which were formerly restricted because of economic, political and social conditions. At the same time, families in transition had to renegotiate a new family contract. 


\section{Endnotes}

${ }^{1}$ The Chinese state encouraged families to sign a Family Support Agreement (FSA), a voluntary contract between parents and adult children to provide support to parents, since the 1980s. FSAs were signed primarily among rural families but could also be found in some urban areas (Chou 2010). An amendment of The Law of The People's Republic of China on the Protection of Rights and Interests of the Elderly was enacted on July 1, 2013 (The State Council of PRC 2012). The amendment made visiting or calling parents regularly a legal obligation, and failure to do so could lead to a lawsuit. However, the frequency of the home-visit was not specified. The law was considered "educational" and served as a starting point of a lawsuit (Hatton 2013).

${ }^{2}$ The seven sets of parents include two cases where both the mother and the father were interviewed (together), three cases where only the father was interviewed, and two cases where only the mother was interviewed. Among the seven sets of parents, five sets of parents had a daughter and two sets of parents had a son. The parent interviewees came from south China (Guangdong Province), southeast China (Zhejiang Province), north China (Liaoning Province, Shandong Province and Inner Mongolia) and mid-west China (Sichuan Province).

${ }^{3}$ The minority of parents who suffered from illnesses such as diabetes and heartrelated problems were mainly looked after by their spouse. One case where Zhaohui's mother was paralysed and was looked after by the father is elaborated on in the paper.

${ }^{4}$ The married sample contains 12 women ( 8 married to a white British/EU citizen, 3 married to a fellow Chinese migrant, 1 married to a Chinese British who was brought up in the UK) and 2 men (both married to a fellow Chinese migrant). The unmarried sample includes migrants who are single ( 5 women and $8 \mathrm{men}$ ) or in a relationship (3 women and 3 men).

${ }^{5}$ To be eligible for long-term visa issued to "elderly dependent relatives", according to the Home Office, "you must prove that: You need long-term care to do everyday personal and household tasks; the care you need is not available or affordable in the country you live in; the person you'll be joining in the UK will be able to support, accommodate and care for you without claiming public funds for at least 5 years" (Home Office 2015).

${ }^{6}$ Both sayings are recorded in the Bible; the Book of Proverbs.

\section{Acknowledgements}

This article is the outcome of a PhD research funded by the Hong Kong Alumni scholarship, University of Kent. The author would like to thank Mr. Michael Deane-White for proofreading the manuscript. Furthermore, this paper benefited from the comments of Professor Stevi Jackson, Dr Jieyu Liu and the two reviewers; their insights and suggestions are much appreciated.

\section{Author's information}

MT is a PhD student in the School of Social Policy, Sociology and Social Research, University of Kent. Her research is about one-child middle class Chinese migrants in the UK and their relationship with parents in China.

\section{Competing interests}

The author declares that she has no competing interests.

Received: 30 December 2015 Accepted: 27 June 2016

Published online: 05 July 2016

\section{References}

Agree, E, B Bissett, and M Rendall. 2003 Summer. Simultaneous care for parents and care for children among mid-life British women and men. Population Trends 112:29-35.

Appadurai, A. 1996. Modernity at large: Cultural dimensions of globalization. Minneapolis: University of Minnesota Press. Baldassar, L. 2007. Transnational families and the provision of moral and emotional support: The relationship between truth and distance. Identities 14(4): 385-409. 
Bodycott, P., and A. Lai. 2012. The influence and implications of Chinese culture in the decision to undertake cross-border higher education. Journal of Studies in International Education 16(3): 252-270.

Bryceson, D., and U. Vuorela. 2002. Transnational families in the twenty-first century. In The transnational family: New European frontiers and global networks, ed. D. Bryceson and U. Vuorela. Oxford: Berg.

Castles, S., and M. Miller. 2009. The age of migration: International population movement in the modern world, 4th ed. London: Palgrave Macmillan.

Chee, M.W. 2003. Migrating for the children: Taiwanese American women in transnational families. In Wife or worker? Asian women and migration, ed. N. Piper and M. Roces, 137-156. Oxford: Rowman \& Littlefield Publishers.

Cheng, Y. 1994. Education and class: Chinese in Britain and the U.S. Aldershot: Avebury.

Chou, R. 2010. Filial piety by contract? The emergence, implementation, and implications of the "family support agreement" in China. The Gerontologist 51(1): 3-16.

Chow, S., and M.H. Chu. 2007. The impact of filial piety and parental involvement on academic achievement motivation in Chinese secondary school students. Asian Journal of Counselling 14(1-2): 91-124. http://hkier.fed.cuhk.edu.hk/ journal/wp-content/uploads/2009/10/ajc_v14n1-2_91-124.pdf. Accessed 14 March 2016.

Croll, E. 2006. The intergenerational contract in the changing Asian family. Oxford Development Studies 34(4): 473-491.

Dai, Y., and M.F. Dimond. 1998. Filial piety: A cross-cultural comparison and its implications for the well-being of older parents. Journal of Gerontological Nursing 24(3): 13-18.

Feng, Z., H. Zhan, X. Feng, C. Liu, M. Sun, and V. Mor. 2011. An industry in the making: The emergence of institutional elder care in urban China. Journal of the American Geriatrics Society 59(4): 738-744.

Fong, V. 2004. Only hope: Coming of age under China's one-child policy. Stanford: Stanford University Press.

Göransson, K. 2009. The binding tie: Chinese intergenerational relations in modern Singapore. Honolulu: University of Hawaii Press.

Hatton, C. 2013. New China law says children 'must visit parents', BBC. http://www.bbc.co.uk/news/world-asia-china-23124345. Accessed 30 Oct 2015

Home Office. 2013. Immigration statistics January to March. https://www.gov.uk/government/publications/immigrationstatistics-january-to-march-2013/immigration-statistics-january-to-march-2013. Accessed 30 May 2015.

Home Office. 2015. Apply to join family living permanently in the UK. https://www.gov.uk/join-family-in-uk. Accessed 15 October 2015

$\mathrm{Hu}, \mathrm{Y}$, and J Scott. 2014. Family and gender values in China: generational, geographic, and gender differences. Journal of Family Issues. Advanced online publication: http://doi.org/10.1177/0192513X14528710.

Hu, Z., and X. Peng. 2015. Household changes in contemporary China: An analysis based on the four recent censuses. The Journal of Chinese Sociology 2: 9.

Hu, R., and N. Ye. 1991. Zhong guo jiu da cheng shi lao nian ren zhiang kuang chou yang diao cha 1988 [Survey of the elderly in nine Chinese cities in 1988]. China: Tianjin Education Press.

Huang, S., and B. Yeoh. 2005. Transnational families and their children's education: China's 'study mothers' in Singapore. Global networks 5(4): 379-400.

lannelli, C., and J. Huang. 2013. Trends in participation and attainment of Chinese students in UK higher education. Studies in Higher Education 39(5): 805-822.

Ikels, C. (ed.). 2004. Filial piety: Practice and discourse in contemporary East Asia. Stanford: Stanford University Press.

Jiang, H. 2009. The impact of aging society on international migration policy. Journal of Nanjing College for Population Programme Management. 25(2): 27-59.

Jiang, C., and J. Hancock. 2013. Absence makes the communication grow fonder: Geographic separation, interpersonal media, and intimacy in dating relationships. Journal of Communication 63(3): 556-577.

Keller, M., W. Edelstein, T. Krettenauer, F. Fu-xi, and F. Ge. 2005. Reasoning about moral obligations and interpersonal responsibilities in different cultural contexts. In Morality in context, ed. W. Edelstein and G. Nunner-Winkler, 317-337. Amsterdam: Elsevier

Lee, E. 1966. A theory of migration. Demography 3(1): 47-57.

Lee, K. 2010. Gender, care work, and the complexity of family membership in Japan. Gender \& Society 24(5): 647-671.

Levitt, P., and N.G. Schiller. 2004. Conceptualizing simultaneity: a transnational social field perspective on society. International Migration Review 38(3): 1002-1039.

Ley, D. 2010. Millionaire migrants: trans-Pacific life lines. MA: John Wiley \& Sons.

Li, C. 2010a. Characterizing China's middle class: heterogeneous composition and multiple identities. In China's emerging middle class: beyond economic transformation, ed. C. Li, 135-156. Washington, D.C: Brookings Institution Press.

Li, H. 2010b. Higher education in China: Complement or competition to US universities? In American universities in a global market, National Bureau of Economic Research (NBER), 269-304. Chicago: University of Chicago Press.

Lin, W. 2011. Beyond flexible citizenship: Towards a study of many Chinese transnationalisms. Geoforum 43: 137-146.

Liu, G. 2006. The right to leave and return and Chinese migration law. Leiden: Martinus Nijhoff Publishers.

Liu, H. 2011. An emerging China and diasporic Chinese: Historicity, state, and international relations. Journal of Contemporary China. 20(72): 813-832.

Ma, Y., Z. Wang, X. Sheng, and M. Shinozaki. 1994. A study of the life and consciousness of contemporary urban family in China: A research in Beijing with comparison among Bangkok, Seoul and Fukuoka. Kitakyushu: Kitakyushu Forum on Asian Women.

Mosneaga, A., and L. Winther. 2013. Emerging talents? International students before and after their career start in Denmark. Population, Space and Place 19: 181-195.

National Bureau of Statistics of China. 2015. Chu guo liu xue ren yuan, xue cheng hui guo liu xue ren yuan [Study abroad population, returned overseas students population (1978-2014)]. http://data.stats.gov.cn/easyquery. $\mathrm{htm}$ ? $\mathrm{cn}=\mathrm{CO1}$.

Nedelcu, M. 2012. Migrants' new transnational habitus: Rethinking migration through a cosmopolitan lens in the digital age. Journal of Ethnic and Migration Studies 38(9): 1339-1356.

Ong, A. 1999. Flexible citizenship. The cultural logics of transnationality. US: Duke University Press.

Ong, A. 2003. Techno-migrants in the network economy. In Global America: the cultural consequences of globalization, ed. U. Beck, N. Sznaider, and R. Winter, 153-173. Liverpool: Liverpool University Press. 
Ong, A., and D. Nonini (eds.). 1997. Ungrounded empires: the cultural politics of modern Chinese transnationalism. London: Routledge.

ONS. 2012. 2011 Census: key statistics for England and Wales. March 2011. Office for National Statistics. http://www.ons. gov.uk/peoplepopulationandcommunity/populationandmigration/populationestimates/bulletins/ 2011censuskeystatisticsforenglandandwales/2012-12-11\#key-points

ONS. 2013a. Migration statistics quarterly report. 2013. Office for National Statistics. http://www.ons.gov.uk/ons/rel/ migration1/migration-statistics-quarterly-report/november-2013/msqr.html.

ONS. 2013b. Immigration patterns of non-UK born populations in England and Wales in 2011. Office for National Statistics. https://www.ons.gov.uk/peoplepopulationandcommunity/populationandmigration/internationalmigration/datasets/ 2011 censusanalysisimmigrationpatternsofnonukbornpopulationsinenglandandwalesin 2011.

Park, K., V. Phua, J. McNally, and R. Sun. 2005. Diversity and structure of intergenerational relationships: Elderly parent-adult child relations in Korea. Journal of Cross-cultural Gerontology 20(4): 285-305.

Parreñas, R. 2005. Long distance intimacy: class, gender and intergenerational relations between mothers and children in Filipino transnational families. Global Networks 5(4): 317-336.

Schans, D., and H. de Valk. 2011. Filial obligations among immigrants and native Dutch: a comparison of perceptions and behaviour among ethnic groups and generations. In Gender, generations and the family in international migration, ed. A. Kraler, E. Kofman, M. Kohli, and C. Schmoll, 99-120. Amsterdam: Amsterdam University Press.

Shi, L. 2009. "Little quilted vests to warm parents' hearts": redefining the gendered practice of filial piety in rural north-eastern China. The China Quarterly 198: 348-363.

Skeldon, R. 1994. Hong Kong in an international migration system. In Reluctant exiles? Migration from Hong Kong and the new overseas Chinese, ed. R. Skeldon, 21-51. Armonk: M. E. Sharpe.

Sun, K. 2014. Reconfigured reciprocity: how aging Taiwanese immigrants transform cultural logics of elder care. Journal of Marriage and Family 76: 875-889.

The State Council of PRC. 2012. Zhong hua ren min gong he guo zhu xi lin (di qi shi er hao), [Order of the President of the People's Republic of China. No. 72]. http://www.gov.cn/flfg/2012-12/28/content_2305570.htm (Chinese). Accessed 3 March 2016.

Tsang, A., J. Irving, R. Alaggia, S. Chau, and M. Benjamin. 2003. Negotiating ethnic identity in Canada: the case of the "satellite children". Youth and Society 34(3): 358-384.

Tsong, Y., and Y. Liu. 2009. Parachute kids and astronaut families. In Asian American psychology: Current perspectives, ed. N. Tewari and A. Alvarez, 365-380. New York: Taylor \& Francis.

Universities UK. 2014. International students in higher education: the UK and its competition. The Funding Environment for Universities 2014. http://www.universitiesuk.ac.uk/policy-and-analysis/reports/Pages/international-students-uk-heits-competition.aspx. Accessed 13 Aug 2015.

Wang, D. 2004. Ritualistic coresidence and the weakening of filial practice in rural China. In Filial piety: Practice and discourse in contemporary East Asia, ed. C. Ikels, 16-33. Stanford: Stanford University Press.

Wang, H., and L. Miao (eds.). 2013. Zhong guo hai gui fa zhan bao gao [Annual Report on the Development of Chinese Returnees] 2013 NO.2.. China: Social Science Academic Press.

Wang, Z. and X Tian. 2015. Zhong guo yang lao ti zhi zhuan xin si kao [Rethinking the reformation of the Chinese pension system]. Xin zheng guan li gai ge [Administration Reform] 5. http://kyhz.nsa.gov.cn/xzxy_kygl/pf/xzxywz/yksInfoDetail. htm?infoid=2544. (Chinese) Accessed 14 March 2016.

Waters, J. 2005. Transnational family strategies and education in the contemporary Chinese diaspora. Global Networks 5: 359-378.

Waters, J. 2011. Time and transnationalism: a longitudinal study of immigration, endurance and settlement in Canada. Journal of Ethnic and Migration Studies 37(7): 1119-1135.

Whyte, M. 2004. Filial obligations in Chinese families: paradoxes of modernization. In Filial piety: Practice and discourse in contemporary East Asia, ed. C. Ikels, 106-127. Stanford: Stanford University.

Wong, L. 2003. Belonging and diaspora: The Chinese and the internet. First Monday 8(4). http://firstmonday.org/issues/ issue8_4/wong/index.html. Accessed 10 Sept 2015.

Wu, B., Z. Mao, and Q. Xu. 2008. Institutional care for elders in rural China. Journal of Aging and Social Policy 20: $218-239$

Xie, Y., and H. Zhu. 2009. Do sons or daughters give more money to parents in urban China? Journal of Marriage and Family 71(1): 174-186.

Yang, G. 2011. The power of the Internet in China. US: Columbia University Press.

Zhan, H.J., and R.J.V. Montgomery. 2003. Gender and elder care in China: The influence of filial piety and structural constraints. Gender \& Society 17(2): 209-229.

Zhan, H., X. Feng, and B. Luo. 2008. Placing elderly parents in institutions in urban China: a reinterpretation of filial piety. Research on Aging 30(5): 543-571.

Zhang, Q. 2012. China's elder-care woes. Shanghai Daily. June 26. http://www.shanghaidaily.com/feature/Chinaseldercare-woes/shdaily.shtml. Accessed 23 May 2016.

Zhang, Y., and W. Goza. 2005. Who will care for the elderly in China? A review of the problems caused by China's one-child policy and their potential solutions. Journal of Aging Studies 20: 151-164.

Zhou, M. 1998. "Parachute kids" in Southern California: The educational experience of Chinese children in transnational families. Educational Policy 12(6): 682-704. 